\title{
Ind i det ukendte med Bataille
}

Georges Bataille:

Den indre erfaring. Larebog $i$ meditation. Efterskrift 1953.

Forelasninger om ikke-viden. At ikke langere ville vare alt. Billedkunstskolernes Forlag, 2013.

348 sider, $250,00 \mathrm{kr}$.

Filosof, antropolog, kunsthistoriker, litterat og skønlitterær forfatter. Franskmanden Georges Bataille (1897-1962) er svær at kategorisere, ligesom hans nyligt genudgivne værk "Den indre erfaring. Lærebog i meditation. Efterskrift 1953. Forelæsninger om ikke-viden. At ikke længere ville være alt", der er en blanding af filosofi og skønlitteratur. Sprogforskeren og forfatteren Per Aage Brandts oversættelse af Batailles værk, der er en samling af større og mindre skrifter - hvoraf "Den indre erfaring" (1943) og "Lærebog i meditation" (1954) er de væsentligste -, så for første gang dagens lys i 1972 på Bibliotek Rhodos. Brandt har siden da revideret sin oversættelse og værket er blevet genudgivet af Billedkunstskolernes Forlag, der tidligere har udgivet værker af blandt andet Giorgio Agamben, Jean Baudrillard og Jean Francois Lyotard. Det er spændende udgivelser og forlaget har tydeligvis fingeren på pulsen, med hensyn til hvad der pt. er oppe i tiden i teoriland. Det bliver interessant at se hvilke nye udgivelser forlaget kommer med i det nye år og Billedkunstskolernes Forlag er derfor værd at holde øje med. Forlaget forstår sig desuden - måske af naturlige årsager? - på design og formår at pakke deres udgivelser enkelt og smukt ind. Særligt med Agamben og Batailles bøger, har forlaget valgt en designmæssig stil, der gør bøgerne lækre at se på. Mere af det, tak!

Værket er som sagt en broget størrelse og også svær at blive klog på. Forskellige genrer krydser ind over hinanden og det er tydeligt, at det er Batailles ambition at ruske op $i$ alt for faste og stabile genrekonventioner. Ud over det de fleste vil kalde "filosofiske" passager, er der også passager i "Den indre erfaring" der næsten ligner uddrag fra en roman eller dagbog, hvor forfatteren beskriver sine - måske, måske ikke - egne subjektive oplevelser. Derudover er der enkelte passager med små og knappe digte. Det synes at være Batailles pointe, at filosofi og skønlitteratur ikke er adskilte 
størrelser, men derimod har meget med hinanden at gøre. Filosofi er skønlitteratur og vice versa; tanker om liv og død kan ikke kun findes hos dem der normalt kategoriseres som "filosoffer", men også hos "forfattere". Det er derfor ikke helt tilfældigt, når Bataille i "Den indre erfaring" tager både filosofiske værker, romaner og digte under kærlig behandling.

Ikke desto mindre skriver Bataille typisk kontinentalfilosofisk, det vil sige dunkelt, tåget og mystisk, der samtidig åbner op for en masse fortolkningsmuligheder. Den fragmentariske form, der pendulerer mellem næsten nietzscheanske pasticher, digte, dagbogsoptegnelser og romanbidder, gør værket til noget af en omgang og det gælder om at holde tungen lige i munden, hvis man har til hensigt at gennemskue Batailles projekt med værket. Under læsningen får man følelsen af at værket er i konstant fare for at kollapse, bryde sammen og ende som den bunke af mere eller mindre usammenhængende tekstbidder den nu engang er. Det er også meningen: Værket er uroligt, drivende fra den ene genre og tanke til den anden, hvilket forstærkes af forfatterens kontinuerlige tvivl om værkets berettigelse og legitimitet. Alt dette underminerer læserens forsøg på at gribe værket $i$ sin helhed og værkets stilistiske form går af den grund fint $\mathrm{i}$ spænd med værkets egentlige budskab eller "filosofi", nemlig rejsen fra det kendte til det ukendte. Eller sagt på Batailleiansk, dét ikke længere at ville være alt.

Hvad betyder det, "ikke længere at ville være alt"? Ifølge Bataille er mennesket karakteriseret ved en menings-drift. Mennesket har behov for at ville være alt, indbefatte alt det sansede og mente i én samlet totalitet, hvor en mening er garanteret. Det er et begær der får samfund til at hænge sammen, da mennesker mødes i forskellige meningsfællesskaber. Det sker først og fremmest igennem sproget, da mennesket forestiller, kender og erkender sin eksistens igennem ord. Sproget eller "diskursen", som Bataille også kalder det - indfanger alt i ord, det er en "sprogets lov" der næsten er usynlig, fordi vi ikke er opmærksom på den. Desværre har menneskets sproglige meningstyranni ført til en "udtørring" af livet og tanken selv er blevet "indskrænket". Ordenes magt er blevet en dårlig vane der hengemmer mennesket i fastlåste verdensopfattelser, uden muligheden for at tænke i alternativer - dog er Bataille lidt flyvsk med hensyn til hvorfor det nu engang er så dårligt at være frosset fast i såkaldte stive opfattelser. 
Her skal "den indre erfaring" træde til, der ifølge Bataille er den redningskrans der skal fiske mennesket op af de stive meningers hav. Den indre erfaring er en vilje til ikke længere at ville være alt, til ikke tvangsmæssigt at indordne alt i én altomfattende mening. Det er en rejse til det menneskeligt muliges yderste, hvor eksisterende meningsdannelser fornægtes, da det begrænser det mulige og ukendte. Af den grund bør den indre erfaring ikke have andet mål end sig selv og ikke tage udgangspunkt i et videnskabeligt, religiøst eller hvilket som helst andet dogme.

Idet man åbner op for den indre erfaring, har man dog allerede sat den som "projekt", en mening, men et negativt projekt og en mening der forsøger at nedbryde al mening. Man skal altså ikke komme uden om sproget og behovet for at indfatte alt $i$ en mening, men dette behov kan dog sagtens stå i nedbrydningens tjeneste og fungere som et første skridt til total meningsfortabelse.

Den indre erfaring fører altså ikke mod et på forhånd givent mål, ingen sikker havn, men til et forvildelsens og ikke-meningens sted, et sted uden for sproget \den diskursive erfaring. Den er udgjort af en ikke-videns princip, der sætter spørgsmålstegn ved alt og spørger $i$ angst og feber. I den indre erfaring kan man ikke med sikkerhed sige hvad man har været vidne til, blot at det er gået ud over ens forstand, hvilket også er hele pointen, da en kategorisering eller navngivning af det oplevede gør det til en "død genstand".

Batailles værk er derfor, som nævnt tidligere, ikke en klassisk akademisk afhandling, henvendt til fagfilosoffer, da dette ville muliggøre en alt for let kategorisering af værket og dermed underminere læserens eventuelle forvirring og nedbrud af genrekonventioner og mere generelt meningstab, der kan associeres med de første trin hen mod en indre erfaring. I stedet er værket uroligt, skævt, usikkert og vibrerende, og det er Batailles hensigt, at læseren skal tage værkets nedbrydningsarbejde på sig og fole det.

Hvordan kommer den så i stand, den indre erfaring? Hvordan når man ud over det kendte og ind $\mathrm{i}$ det ukendte? Blandt andet igennem kunsten og poesien, der kan åbne op for sprækker i det bestående og derigennem muliggøre den indre erfaring og give mennesket "en aldrig bereden hests frihed".

Hensigten med den indre erfarings nedbrydning af fasttømrede meninger, er ikke at leve et liv uden for sproget, i totalt kaos og 
løsrivelse fra objekterne omkring en. Det er ifølge Bataille en naiv utopi. I stedet skal den indre erfaring åbne op for et mulighedsrum, hvor nye og anderledes meningsdannelser kan finde sted. Batailles pointe er, at man ikke kan komme uden om sproget, da den menneskelige eksistens er bundet op på sproget, på godt og ondt.

For læsere af de franske filosoffer Jacques Derrida, Jean-Luc Nancy, Jacques Lacan, Julia Kristeva, Michel Foucault, Gilles Deleuze, med flere, bør "Den indre erfaring" være af stor interesse. Førnævnte filosoffer har i dén grad været inspireret, måske ikke i særdeleshed af "Den indre erfaring", så i hvert fald af Batailles filosofiske œuvre i det hele taget. Der er tydeligvis en parallel mellem de nævnte filosoffers pointering om, at al mening $\mathrm{i}$ bund og grund er ustabil og af den grund bør udfordres, og Batailles forestillinger om sproget og den indre erfarings egenskaber. "Den indre erfaring" er idehistorisk interessant og relevant, foruden at den er en syret, mærkelig og næsten berusende rejse i sig selv.

Philip Martinussen 